\title{
Advertising Status and Legitimacy: or, Why Did Henry VIII's Queens and Children Patronize Travelling Performers?
}

\begin{abstract}
Patronage of travelling performers by English kings seems to have been one way of displaying royal power, prestige, and status. Beginning with Edward IV and continuing through Henry VIII, queens and royal offspring also gave their names to travelling performance troupes. Chronologies of the travelling troupes of queens and royal offspring suggest that during the reign of Henry VIII, as queens and heirs presumptive changed, one likely purpose of these troupes was to advertise and legitimize the status of their royal patrons.
\end{abstract}

To date, the volumes published in the University of Toronto's Records of Early English Drama project provide performance data from over half of Tudor England: sixteen counties, nine municipalities, and Wales. Information found in Ian Lancashire's Dramatic Texts and Records of Britain, the Malone Society's Plays and Players in Norfolk and Suffolk, and a few other sources augments this data. ${ }^{1}$ Taken together, these printed sources provide thousands of entries detailing locale-specific performance activities for large and small communities. ${ }^{2}$ More will appear as further volumes of the REED series appear.

The superb editorial apparatus for REED volumes provides information about the historical background and performance activities of the locale, lists of documents consulted with descriptions, statements of editorial procedure, notes and appendices, translations of entries in Latin, and glossaries of Latin and English. When perusing the actual entries transcribed from the original sources, however, readers may find the vast amount of data daunting at first glance. How, for example, does one organize and analyze entries like: 'xx s. ad ystrionibus at feat of Translacionis' (1365 Christ Church Priory, Canterbury), 'payd $24 \mathrm{~d}$, seruo domini rege' (1510 Mettingham College, Suffolk),

James H. Forse (jforse@bgsu.edu) is professor emeritus in the department of History at Bowling Green State University. 
'ad Regis histrionibus vocate waytes, 20 d' (1517 Hickling Priory, Norfolk), 'viii s to Englishe and other the kynges players for an enterlude' (1520 Dover, Kent)? 3

Thanks to computers, the vast array of entries from parish, municipal, household, and monastic records found in REED volumes and on the REED Patrons and Performances Web Site can be brought together to compare data over time and place. ${ }^{4}$ For this study (and previous ones) ${ }^{5}$ I use a spreadsheet I began in the very early 1990s, updated as new REED volumes appeared and the REed Patrons and Performances Web Site came online, augmented by data from Ian Lancashire's Dramatic Texts and Records of Britain, the Malone Society's Plays and Players in Norfolk and Suffolk, and a few other sources such as J.T. Murray's English Dramatic Companies, The Register of Thetford Priory, and Extracts from the Account Rolls of the Abbey of Durham. ${ }^{6}$ The spreadsheet compiles data from one of the earliest records (1277), about performers travelling around England when 'ystrioni' were paid one shilling at Christ Church Priory, ${ }^{7}$ under the patronage of King Edward I until the end of the reign of James I (1625). The spreadsheet lists travelling troupes by patron or place of origin, dates and places of performances, and fees paid to the players if such information was recorded. Though more data will emerge as the REED volumes continue to be published, the amount now available gives a large enough sample from most areas of Tudor England to suggest some broad patterns within the data, patterns that in turn may suggest avenues for further study.

As background I offer a brief sketch of touring royal entertainers ${ }^{8}$ mentioned in provincial records dating back to the reign of Edward I. ${ }^{9}$ Records to date reveal that every successor to Edward I had performers playing at locales other than at court, and not necessarily locales where the kings themselves were present. While their main raison d'être was to entertain the monarchs and their courts, the touring of the performers also may have served to augment, or perhaps 'farm-out', whatever stipends they received from their patrons. We must remember, however, that these performers were the servants of their patrons and would not be touring unless their masters had given them leave. Hence, their mere presence in a locality while touring indirectly served to represent or 'advertise' the royal presence and power to subjects, and especially to local authorities, around the realm.

Leonard Tennenhouse suggests touring royal troupes, like royal progresses, may have been a form of Power on Display (to quote his book title). ${ }^{10}$ Touring players also perhaps informally functioned as low-level messengers 
and intelligencers. ${ }^{11}$ I suggest that the frequency of royal entertainers visiting County Kent may hint at these purposes. My spreadsheet indicates that beginning in the reign of Richard II, and continuing through the reign of James I, royal troupes appeared in County Kent more often than any other region in England. ${ }^{12}$ In addition, the Crown's chief representatives in the area, the lords warden of the Cinque Ports, also had troupes of performers touring Kent and neighboring Sussex ${ }^{13}$ in the 1500 s - every lord warden save one. ${ }^{14}$ Kent was a county lacking controls found in most other counties. It lacked major secular lords, and possessed a large number of chartered towns and other semi-independent liberties, which made much of the county almost independent of the royal sheriffs. In fact, the office of lord warden was created after the Cinque Ports sided with Simon de Montfort in the Second Barons' War against Henry III (1264-70); from Kent came Wat Tyler's rebellion in 1381, Jack Cade's rebellion in 1450, the last gasp of resistance to the restoration of Edward IV in 1471, and the beginnings of Buckingham's rebellion against Richard III in 1483 (and later the threat of revolt against Edward VI in 1549-50 and Wyatt's rebellion against Mary in 1554). ${ }^{15}$ Perhaps England's monarchs thought they needed more eyes and ears and their presences well advertised and represented in such an independent-minded and turbulent county.

One intriguing pattern in the spreadsheet is what seems to be significantly larger numbers of provincial records indicating touring activity by royal entertainers attached to queens and royal offspring. This trend begins in the last half of the reign of Edward IV and continues through the reigns of Henry VII (see Appendix), and Henry VIII — a pattern that does not appear in earlier reigns. Granted, extant sources become more numerous and complete in the last half of the 1400s, but even so, the increase seems striking. One plausible explanation for this phenomenon may be the uncertainties of legitimacy for these monarchs and their desire to assert that legitimacy. Touring by performers patronized by the king, the queen, and their sons spiked after Edward IV regained his throne in 1471. Touring by performers of Richard III's queen and son begins immediately after he seized the throne in 1483 . Touring by performers of Henry Tudor's queen and sons surpassed that of his predecessors. Henry's claims to the throne and the legitimacy of his dynasty were genealogically weak, and Henry faced two armed challenges from Yorkist pretenders.

Given the tumultuous nature of Henry VIII's reign — as wives and heirs came and went - I decided to focus attention here on touring entertainers 
whom Henry's queens and offspring patronized. Provincial records reveal performers identified as the servants of Henry's successive queens appearing in Bristol, Kent, Devon, Norfolk, Oxford, Cambridge, Southampton, Dorset, Essex, Shropshire, and Worcester. To date there are twenty-eight instances in eleven counties of performances by queens' performers between 1517 and 1547. ${ }^{16}$ The records also show that Henry's children were patrons of performers, and that the troupes of his royal offspring played more often, and in more locations, than those of his queens. Accounts from eighteen counties - Bristol, Cambridge, Cornwall, Devon, Hampshire, Kent, Lancashire, Leicestershire, Lincolnshire, Middlesex, Norfolk, Oxford, Shropshire, Suffolk, Surrey, Sussex, Worcester, and York — from 1525-47 total 128 provincial performances by entertainers identified as servants of Henry's children. ${ }^{17}$

First, as seen in the following table, let us track the history of performers attached to Henry's queens as they appear in provincial records published to date.

Table 1: Provincial Appearances of Queens of Henry VIII

\begin{tabular}{lllll}
\hline \multicolumn{1}{c}{ Patron } & Year & \multicolumn{1}{c}{ Place } & \multicolumn{1}{c}{ County } & \multicolumn{1}{c}{ Type } \\
\hline Katherine of Aragon & 1517 & Worcester & Worcester & Minstrels \\
Katherine of Aragon & 1518 & Worcester & Bristol & Minstrels \\
Katherine of Aragon & 1520 & Sandwich & Kent & Bearward \\
Katherine of Aragon & 1528 & Thetford & Norfolk & Players \\
Katherine of Aragon & 1530 & Southampton & Hampshire & Players \\
Katherine of Aragon & 1530 & Southampton & Hampshire & Players \\
Katherine of Aragon & 1531 & Magdalen College & Oxford & Players \\
Katherine of Aragon & $\mathbf{1 5 3 3}$ & annulled & & \\
Anne Boleyn & 1533 & Exeter & Devon & Minstrels \\
Anne Boleyn & 1533 & Worcester & Worcester & Players \\
Anne Boleyn & 1533 & Cambridge & Cambridge & Minstrels \\
Anne Boleyn & 1533 & Crowle & Worcester & Minstrels \\
Anne Boleyn & 1533 & Crowle & Worcester & Minstrels \\
Anne Boleyn & 1534 & Battenhall & Worcester & Players \\
Anne Boleyn & 1535 & Dover & Kent & Players \\
Anne Boleyn & 1535 & Canterbury & Kent & Minstrels \\
Anne Boleyn & $\mathbf{1 5 3 6}$ & beheaded & & \\
Jane Seymour & 1536 & Court (Whitehall) & Middlesex & Players \\
Jane Seymour & 1536 & Shrewsbury & Shropshire & Players
\end{tabular}


Table 1: Provincial Appearances of Queens of Henry VIII (cont'd)

\begin{tabular}{lclll}
\hline \multicolumn{1}{c}{ Patron } & Year & \multicolumn{1}{c}{ Place } & \multicolumn{1}{c}{ County } & \multicolumn{1}{c}{ Type } \\
\hline Jane Seymour & 1536 & Shrewsbury & Shropshire & Players \\
Jane Seymour & $\mathbf{1 5 3 7}$ & died & \\
Catherine Howard? & 1540 & Court (Whitehall) & Middlesex & Players \\
Catherine Howard & 1541 & Court (Whitehall) & Middlesex & Players \\
Catherine Howard & $\mathbf{1 5 4 2}$ & beheaded & & \\
Catherine Parr & 1543 & Canterbury & Kent & Players \\
Catherine Parr & 1544 & Queen's College & Cambridge & Players \\
Catherine Parr & 1545 & Dover & Kent & Players \\
Catherine Parr & 1546 & Maldon & Essex & Players \\
Catherine Parr & 1547 & Bristol & Bristol & Players \\
Catherine Parr & 1547 & Dover & Kent & Players \\
Catherine Parr & 1547 & Maldon & Essex & Players \\
Catherine Parr & 1547 & Norwich & Norfolk & Players \\
Catherine Parr & $\mathbf{1 5 4 7}$ & widowed & & \\
\hline
\end{tabular}

Queen Katherine of Aragon originally came to England at the age of fifteen to marry Henry VII's heir apparent Arthur, prince of Wales. Her expected landing was Southampton, but because of storms her ship put in at Plymouth, 150 miles away, on 2 October 1501. Plymouth's inhabitants gave her an enthusiastic welcome, ${ }^{18}$ and there appears the first mention of entertainers named as Katherine's servants. Plymouth's records indicate two performances by the princess's minstrels. ${ }^{19}$ From Plymouth Katherine proceeded to Exeter where on 7 October she met King Henry VII's official welcoming party. ${ }^{20}$ Here, according to Exeter's records, her entertainers again performed. ${ }^{21}$ What seems unclear is whether these entertainers were part of her original entourage, a troupe created at Henry's court and dispatched from Southampton to Plymouth, or a troupe created on the spot in her honour. From Exeter Katherine proceeded to London, where on 14 November she married Prince Arthur. The marriage was short-lived, a little over four months; after the couple had settled at Ludlow, the seat of the prince of Wales, Arthur died 2 April 1502. ${ }^{22}$

After the events in Plymouth and Exeter, entertainers identified as Katherine's servants do not appear in records again until two years later. By then the now-widowed princess of Wales had returned to London; Henry VII and Ferdinand and Isabella of Spain had begun negotiations for her marriage 
to the new prince of Wales, the future Henry VIII. Negotiations dragged on for the next seven years, with Katherine's status in limbo, her household and household allowances severely reduced. ${ }^{23}$ Perhaps the reappearance of entertainers under her name - minstrels performing at Furnival's Inn (inns of chancery) in 1503, and musicians performing at Canterbury in $1507^{24}$ was one way Katherine attempted to advertise or assert status. Interestingly, Katherine's and Prince Henry's musicians were visiting Canterbury together in 1507 . Perhaps it was a way to link her with Henry in a year when Katherine's status and chances of marrying Prince Henry seemed especially bleak. But her prospects changed swiftly. Henry VII died 21 April 1509, and the new King Henry VIII announced his intention to marry Katherine. The pair married 11 June, and on 24 June they were jointly anointed and crowned king and queen of England at Westminster Abbey. ${ }^{25}$

Performers travelling under the patronage of the now Queen Katherine first appear in records from Worcester in 1517, which note the joint presence there of the king's and the queen's minstrels, but it is unclear if they performed. A joint performance of the king's and the queen's minstrels is mentioned in Bristol's records the next year, 1518. The queen's bearward performed in Sandwich in $1520 .{ }^{26}$ Henry and Katherine were together on progresses in 1517 and $1518,{ }^{27}$ and the period from about 1510 to 1525 marks a time when Katherine was being presented with her husband as almost a co-ruler. The joint appearance in provincial records of the king's and the queen's minstrels in 1517 and 1518, while the pregnant queen was on progress with her king, may be an outward manifestation of that status. She usually accompanied Henry on his annual progresses, and was prominent during his famous Field of Cloth of Gold meeting with Francis I in 1520. Katherine had been named regent in 1513, when Henry was at war in France. During her regency she organized the English forces that achieved a crushing victory over the Scots at the Battle of Flodden. In this time she also had several pregnancies (1510, 1511, 1513, 1514 twice, 1516, 1518, 1519). Though only their daughter Princess Mary (born 1516) survived, Katherine had given birth to three short-lived sons before Mary's birth, and Henry seemed to have high hopes for a male heir. He reportedly said at Mary's birth: 'We are both young. If it was a daughter this time, by the grace of God the sons will follow'. By 1525, however, the queen was almost forty. It seemed unlikely that she could conceive again, and Henry already was beginning to court Anne Boleyn. ${ }^{28}$

After 1518, performers named as Katherine's servants do not appear in provincial records again until ten years later, when accounts from Thetford 
Priory (Norfolk) record a twelve-pence payment to them in $1528 .{ }^{29}$ According to records from Southampton and from Magdalen College, Oxford, Queen Katherine's players toured there, respectively, in 1530 and $1531 .^{30}$ Perhaps Katherine was attempting to maintain and advertise her status as legitimate queen. In 1527, during negotiations concerning a possible marriage of Princess Mary to Francis I, the French Bishop of Tarbes raised questions about the legitimacy of Henry's marriage to her mother, and at the same time Henry was beginning overt legal steps to seek an annulment. That same summer Anne Boleyn seemed to attain the status of consort when she accompanied Henry on his royal progress. ${ }^{31}$ By 1530 Henry's efforts to secure an annulment were in full swing, but Katherine was doing her best to prevent the annulment and assert her legal position as queen. Her elaborate 'pilgrimage' to the shrine of the Virgin at Walsingham in 1513 to celebrate Henry's victory in France at the Battle of the Spurs and her victory over the Scots at Flodden ${ }^{32}$ shows that Katherine knew the value of advertising her royal status. But in 1531, the last year Katherine's players appear in provincial records, Henry ended any pretence of the two living together as king and queen. He sent Katherine away from court, separated her from her daughter Mary, and turned her quarters over to Anne Boleyn. ${ }^{33}$

On 14 November 1532 Henry 'secretly' married Anne Boleyn at Dover, where the two had landed after a trip to France to meet with Francis I and formalize a treaty of mutual aid with France. Sometime in December Anne became pregnant. By Easter (April of 1533) Anne appeared formally as Henry's wife and queen. On 1 June with lavish ceremony, Anne was crowned queen of England at Westminster. On 7 September she gave birth to the future Elizabeth I. Henry and the court expressed no public disappointment at the birth of a girl, but jousts originally scheduled as part of the christening celebrations were cancelled. ${ }^{34}$

David Starkey writes that Anne 'wanted to make sure her title as queen would be unimpeachable'. Henry, Anne, and her faction realized Katherine's popularity with the commons (some sources, like the French ambassador Chapuys, suggest disapproval of Anne was evident during her coronation procession); the ceremonies surrounding her formal entry into London and her coronation were designed to exceed and overshadow any celebrations connected with Katherine - in other words, to advertise Anne's status as the rightful queen. ${ }^{35}$ So perhaps it is not mere coincidence that the Exeter records identify a troupe as Queen Anne Boleyn's minstrels in 1533, the year of her coronation, and birth of the future Elizabeth I. ${ }^{36}$ 
Just as Anne appropriated Katherine's quarters, jewels, barge, ${ }^{37}$ and title, she seems to have appropriated Katherine's entertainers, as well as John and William Slye from Princess (now Lady) Mary's defunct troupe. ${ }^{38}$ Queen Anne's players also appear in records from Worcester in 1533, and from Cambridge, and Crowle, Worcestershire, where they performed twice. In just this one year, records published to date indicate that provincial appearances by Anne's performers equal the total number of such appearances by Queen Katherine's performers over her entire twenty-four years as Henry's queen. ${ }^{39}$ Anne's performers continued to tour under her name for the following two years, appearing in records from Battenhall, Worcestershire in 1534, and from Dover in 1535. Might it be that Anne believed it prudent to advertise her status as queen while the popular ex-queen was still alive in 'retirement' fifty miles from London at Kimbolton? ${ }^{40}$ It does seem probable that Queen Anne used drama, as did Thomas Cromwell and the earl of Oxford, as a means to propagandize Protestant reforms and the break with Rome. $^{41}$

The last mention of Queen Anne's entertainers in provincial records comes from Canterbury in 1535,42 the year the marriage began to sour. Anne may have had a miscarriage that year, and historians believe Henry already was thinking of a new wife. After Anne miscarried again — the day of Katherine of Aragon's funeral (29 January) - her days as queen were numbered. By February 1536 Henry openly was showing favour to Lady Jane Seymour. On 2 May Anne was arrested and sent to the Tower. On 15 May she was tried, convicted, and condemned for treason on grounds of adultery and incest. Her marriage to Henry was annulled, and she was beheaded 19 May 1536.43

One day after Anne's execution Henry formally betrothed himself to Jane Seymour. Ten days later she became Henry VIII's third wife. She was proclaimed queen on 4 June. ${ }^{44}$ In 1536, John Slye is named among the players of Queen Jane Seymour, suggesting Anne's entertainers passed on to her successor. To date there only are three records of her troupe's performances one at court in 1536, and two in Shrewsbury, Shropshire in 1536 and 1537 - but, of course, Jane's death on 24 October 1537, twelve days after the birth of the future Edward VI, cut her reign short. ${ }^{45}$

Henry remained a widower for over three years, so for those years there were no queen's performers. After negotiations lasting about a year, a marriage was arranged with Anne, the sister of the duke of Cleves. Anne arrived in England on 27 December 1539, and first met Henry on New Year's Eve. ${ }^{46}$ 
The day after that meeting, Henry is reported as saying that, if he knew before she landed what he now knew, 'she should not have come within this realm. ${ }^{47}$ He postponed the scheduled marriage, seeking a way out, but was trapped by the formal diplomatic and prenuptial agreements he already had signed. Henry and Anne married on 8 January 1540. The day after the wedding Henry informed his intimates that the marriage was not consummated. Nor was it ever to be. For the next six months, though Henry and Anne outwardly seemed a couple, he was pushing his ministers to annul the marriage. Anne never was crowned queen. By May Henry openly was seeking the company of one of Anne's ladies-in-waiting, Catherine Howard. On 24 June Anne was ordered to leave court; on 9 July, a convocation of bishops declared the marriage null and void. Anne accepted the decree and the generous settlement Henry gave her. Given Henry's determination first to avoid, and then to end the marriage, it is not surprising that no entertainers under this queen's patronage appear in provincial records. ${ }^{48}$

A month after the decree of annulment, Henry married Catherine Howard at Hampton Court. Some scholars believe her uncle, the duke of Norfolk, abetted by Bishop Gardiner of Winchester, purposefully put her in Anne of Cleves's entourage, hoping she would catch Henry's fancy, and thereby benefit the family and conservative religious faction at court. Historical fiction certainly adopts that view. Certainly, Norfolk and Gardiner were able to use Henry's determination to end the marriage with Anne of Cleves to bring down its principal architect, and supporter of further religious reforms, Thomas Cromwell. ${ }^{49}$ The only reference to Queen Catherine Howard's performers may well be a celebration of that factional triumph. During Christmas celebrations in 1540, her players entertained the court with a play named Godly Queen Hester. Several scholars believe the play was meant as an allegory, paralleling the biblical queen Esther, her sponsor and relative Mordecai, and their roles in the downfall of the evil minister Haman with Queen Catherine Howard, her uncle Norfolk, and the downfall of Thomas Cromwell..$^{50}$ Less than two years later Queen Catherine had her own downfall. Within days of Henry's and Catherine's return from a progress to York, accusations of infidelity and pre-marital sexual activity resulted in her arrest in November 1541. Catherine was stripped of her title, attainted for treason in January 1542, and beheaded on 13 February. ${ }^{51}$

Seventeen months later (12 July 1543) there was a new Queen Catherine (Parr). ${ }^{52}$ Twice widowed, her two late husbands had been prominent nobles, Sir Edward Burgh and Lord Latimer. How she came to Henry's attentions is 
unclear, but Catherine's family had a long-standing position at court, dating back to the reign of Edward IV. Her father Thomas Parr had been an esquire of the body to Henry VII, and her sister one of the chief ladies-in-waiting to Queens Jane Seymour, Anne of Cleves, and Catherine Howard. ${ }^{53}$ Apparently she became a staunch supporter of the religious reform party around the time of the Pilgrimage of Grace, and later as queen staffed her household with women who shared her views. She endeared herself to Henry, so much so that he named her regent during his campaign in France in July and August 1544. Though Henry's sympathies and support swung back and forth from the conservative to the reformist factions, Catherine encouraged and supported the writing and publication of works promoting the Protestant cause, and used her influence with Henry to protect the reformers. At one point, in 1545, she was in danger of being arrested for heresy, but averted the plot that Lord Chancellor Wriothesley and Bishop Gardiner hatched against her. ${ }^{54}$

Possibly because of these uncertainties at court, and her Protestant sympathies, Queen Catherine's entertainers were as active in the provinces as had been those of Anne Boleyn. Their presence in the provinces is recorded every year during her tenure as queen consort - in accounts from Canterbury (1543), Cambridge (1544), Dover (1545 and 1547), Maldon, Essex (1546 and 1547), Norwich (1546), and Bristol (1547). ${ }^{55}$ Given the fact that Henry gave her free reign in 1544 in reorganizing her household, ${ }^{56}$ it seems plausible that Catherine herself may have sent her players out to promote her status, and possibly also Protestant reforms. Catherine was a patron of Nicholas Udall, who wrote two anti-papal plays, Ezechias and De Papatu. She could have been following the examples of Queen Anne Boleyn, the earl of Oxford, and Thomas Cromwell, whom we know were connected to an acting company led by John Bale that performed pro-Protestant plays about the kingdom. ${ }^{57}$ We get a hint that such might be the case from the Norwich records, which indicate a reward to her players 'for an interlude whose matter was the market of mischief'. This interlude might have dramatized Thomas Cromwell's exposé of the Rood from Boxley Abbey in 1538, when, in marketplaces in Maidstone and London, he revealed the hidden machinery that made the lips of the idol move. In January 1547, Henry died. The now Dowager Queen Catherine retired from court, and of course, no longer patronized a royal troupe of entertainers. ${ }^{58}$

Three of Henry's children are also recorded in provincial records as patrons of travelling entertainers. One might view performers patronized by Henry's wives as ongoing employees of the 'office' of the queen. As such, it is not 
entirely clear whether their touring was at the will of that particular queen, or Henry, or both. But Henry created new households and courts for his children, who, when their courts were established, were children - respectively, Mary at nine years of age, Henry Fitzroy at six, and Edward, a babe in arms. Henry's appointed guardians staffed their charges' respective households and councils and maintained close contacts with court. For example, in November 1525, members of Princess Mary's council wrote Cardinal Wolsey asking permission to arrange interludes or plays for Christmas celebrations at her court. ${ }^{59}$ Under those circumstances, it seems unlikely that the child-patrons, on their own, sent entertainers about the kingdom to advertise their royal status.

Performers attached to the households of two of Henry's children, Princess Mary and Henry Fitzroy, were touring the provinces roughly at the same time, paralleling similar practices carried out in the reigns of his grandfather, Edward IV, and his father, Henry VII (see Appendix). The following table tracks their activities as reflected in provincial records published to date.

Table 2: Provincial Appearances of Princess Mary's and Henry Fitzroy's Entertainers

\begin{tabular}{lrllll}
\hline \multicolumn{1}{c}{ Patron } & Year & \multicolumn{1}{c}{ Status } & \multicolumn{1}{c}{ Place } & \multicolumn{1}{c}{ County } & \multicolumn{1}{c}{ Type } \\
\hline Princess Mary & 1525 & P. of Wales & Sleaford & Lincoln & Players \\
Princess Mary & 1525 & P. of Wales & Ludlow & Shropshire & Players \\
Princess Mary & 1525 & P. of Wales & Worcester & Worcester & Players \\
Princess Mary & 1525 & P. of Wales & Battenhall & Worcester & Minstrels \\
Princess Mary & 1526 & P. of Wales & Shrewsbury & Shropshire & Players \\
Princess Mary & 1526 & P. of Wales & Worcester & Worcester & Players \\
Princess Mary & 1527 & P. of Wales & Worcester & Worcester & Minstrels \\
Princess Mary & 1527 & P. of Wales & Shrewsbury & Shropshire & Players \\
Princess Mary & 1529 & P. of Wales & Court & Middlesex & Players \\
Princess Mary & 1530 & P. of Wales & Bristol & Bristol & Players \\
Princess Mary & 1530 & P. of Wales & Leicester & Leicester & Players \\
Princess Mary & 1530 & P. of Wales & Court & Middlesex & Players \\
Princess Mary & 1530 & P. of Wales & Magdelan & Oxford & Players \\
Princess Mary & 1530 & P. of Wales & Chrewsbury & Shropshire & Players \\
Princess Mary & 1530 & P. of Wales & Worcester & Worcester & Players
\end{tabular}


Table 2: Provincial Appearances of Princess Mary's and Henry Fitzroy's Entertainers (cont'd)

\begin{tabular}{|c|c|c|c|c|c|}
\hline Patron & Year & Status & Place & County & Type \\
\hline Princess Mary & 1531 & P. of Wales & Ludlow & Shropshire & Players \\
\hline Princess Mary & 1531 & P. of Wales & $\begin{array}{c}\text { Whalley } \\
\text { Abbey }\end{array}$ & Lancashire & Minstrels \\
\hline Princess Mary & 1531 & P. of Wales & Leicester & Leicester & Players \\
\hline Princess Mary & 1531 & P. of Wales & $\begin{array}{l}\text { Court } \\
\text { [Whitehall] }\end{array}$ & Middlesex & Players \\
\hline Princess Mary & 1531 & P. of Wales & Worcester & Worcester & Players \\
\hline Princess Mary & 1532 & P. of Wales & Dover & Kent & Players \\
\hline Princess Mary & 1531 & P. of Wales & Crowle & Worcester & Players \\
\hline Princess Mary & 1532 & P. of Wales & Dover & Kent & Players \\
\hline Princess Mary & 1532 & P. of Wales & Battenhall & Worcester & Players \\
\hline Princess Mary & 1532 & P. of Wales & Worcester & Worcester & Bearward \\
\hline Princess Mary & 1532 & P. of Wales & Bristol & Bristol & Players \\
\hline Princess Mary & 1533 & P. of Wales & Dover & Kent & Players \\
\hline Princess Mary & 1533 & P. of Wales & Shrewsbury & Shropshire & Players \\
\hline Princess Mary & 1533 & bastardized & & & \\
\hline Henry Fitzroy & 1527 & D. Richmond & Exeter & Devon & Players \\
\hline Henry Fitzroy & 1527 & D. Richmond & Bardley & Lincoln & Bearward \\
\hline Henry Fitzroy & 1527 & D. Richmond & Bridgwater & Somerset & Minstrels \\
\hline Henry Fitzroy & 1528 & D. Richmond & Bardley & Lincoln & Bearward \\
\hline Henry Fitzroy & 1528 & D. Richmond & New Romney & Kent & Minstrels \\
\hline Henry Fitzroy & 1529 & D. Richmond & Rye & Sussex & Players \\
\hline Henry Fitzroy & 1530 & D. Richmond & $\begin{array}{l}\text { Bury St } \\
\text { Edmund's }\end{array}$ & Suffolk & Players \\
\hline Henry Fitzroy & 1530 & D. Richmond & Shrewsbury & Shropshire & Bearward \\
\hline Henry Fitzroy & 1532 & D. Richmond & Bristol & Bristol & Players \\
\hline Henry Fitzroy & 1532 & D. Richmond & Selby Abbey & York & Players \\
\hline Henry Fitzroy & 1532 & D. Richmond & Bristol & Bristol & Bearward \\
\hline Henry Fitzroy & 1533 & D. Richmond & Cambridge & Cambridge & Players \\
\hline Henry Fitzroy & 1533 & D. Richmond & Sandwich & Kent & Bearward \\
\hline Henry Fitzroy & 1533 & D. Richmond & Exerter & Devon & Minstrels \\
\hline Henry Fitzroy & 1534 & D. Richmond & Rye & Sussex & Bearward \\
\hline Henry Fitzroy & 1534 & D. Richmond & Bristol & Bristol & Bearward \\
\hline Henry Fitzroy & 1536 & D. Richmond & Bristol & Bristol & Bearward \\
\hline Henry Fitzroy & 1536 & died & & & \\
\hline
\end{tabular}


The table suggests interesting coincidences about the appearances of their respective performers in provincial records and events in the lives of Henry's offspring.

Princess Mary was the only surviving child of Henry and Katherine of Aragon, and until the divorce his putative heir. In 1525 at the age of nine she was sent to Ludlow to preside over the Council of Wales and given her own household and court, numbering over 300 officers and servants, costing $£ 5000$ per year. In effect Mary became de facto princess of Wales. ${ }^{60}$ That same year Princess Mary's performers appear in provincial records for the first time. Henry even transferred two players from his personal troupe of entertainers, John and William Slye, to start up his daughter's new troupe. ${ }^{61}$ As might be expected, Mary's players performed more often in Shropshire (Ludlow, 1525 and 1531, Shrewsbury, 1527, 1530, 1533), ${ }^{62}$ the locale of her court, than elsewhere. Yet her entertainers also performed in seven other counties - Lincolnshire (Sleaford, 1525), Leicestershire (Leicester, 1530 and 1531) ${ }^{63}$ Bristol (1530 and 1533), Oxford (Magdelan College, 1530), Worcestershire (Worcester, 1525, 1526, 1527, 1530, 1532, Battenhall, 1532, Crowle, 1531), Lancashire (Whalley Abbey, 1531), and Kent (Dover, twice in 1532 and 1533). ${ }^{64}$ As a singular recognition of her status and favour, Princess Mary's troupe also performed three times before Henry's court at Whitehall $(1529,1530,1531){ }^{65}$ In 1533, however, as a result of Henry's annulment of his marriage to Katherine of Aragon, Princess Mary was demoted to Lady Mary, the king's bastard daughter; performers under her patronage disappear from the records.

In 1525 - the same year Henry made Princess Mary de facto princess of Wales - many historians believe he was also hedging his bets concerning his successor. It was doubtful that Queen Katherine, now forty, would bear any more children. ${ }^{66}$ In June Henry named his six-year-old bastard son, Henry Fitzroy, duke of Richmond. From his birth Henry was extremely fond of the boy, and took an interest in his upbringing. ${ }^{67}$ Granting Henry Fitzroy the title of duke of Richmond has significance as a quasi-legitimization of his potential as an heir. The earldom of Richmond was the Tudor family's personal title - the title created for Henry VIII's grandfather, Edmund Tudor, and held by his father, Henry VII, before he defeated Richard III to become king. As time went on, Henry heaped more honours upon his bastard son; he installed Henry Fitzroy as a Knight of the Garter, gave him the additional titles of duke of Somerset, earl of Nottingham, lord high admiral, president of the council of the North, warden of the Scottish Marches — with a large, 
formal household and court at Sheriff Hutton in Yorkshire — and in 1536, lord warden of the Cinque Ports, and lord lieutenant of Ireland. There was talk about making him king of Ireland. ${ }^{68}$ Taken together his titles and offices raised him in status and prestige above all the nobles of England. A little more than 100 years later (1660), the historian/antiquarian Thomas Fuller opined that had Fitzroy survived Henry, he might have been placed ahead of Mary and Elizabeth in the succession.69

In 1527, about the time Henry began more serious pursuit of an annulment from Katherine of Aragon, performers under Fitzroy's patronage appear in the accounts of Exeter (Devon) and Bridgwater (Somerset), and, in 1527 and 1528, a bearward under his patronage appears in records from Bardley, Lincolnshire. ${ }^{70}$ Accounts from counties Kent (New Romney, 1528, Sandwich, 1533), Sussex (Rye, 1529), Suffolk (Bury St Edmund's, 1530), Bristol (1532, 1534), Shropshire (Shrewsbury, 1530), York (Selby Abbey, 1532), Cambridge (Cambridge, 1533), and Devon (Exeter, 1533) give further evidence of touring by Fitzroy's players, minstrels, and bearwards. ${ }^{71}$

In records to date, appearances by Fitzroy's entertainers cease in 1534, less than a year after the birth of Henry's legitimate (for a time) Princess Elizabeth on 7 September 1533. Two years later, however, in 1536, Elizabeth was bastardized when Henry annulled his marriage to Anne and beheaded her. In June a new Act of Succession declared that Henry VIII could name his successor whether of legitimate birth or not. ${ }^{72}$ In the same year Fitzroy was named lord warden of the Cinque Ports, an honour Henry himself held when prince of Wales. Coincidentally, perhaps, Fitzroy's bearward reappears on tour in Bristol's records. ${ }^{73}$ It seems Fitzroy was back in the running, but he died in July 1536.

On 12 October 1537 Henry finally had his longed-for, legitimate, male heir, when Queen Jane Seymour gave birth to the future Edward VI. ${ }^{74}$ The following table details the provincial activities of Prince Edward's entertainers in the records published thus far.

Table 3: Provincial Appearances of Prince Edward's Entertainers

\begin{tabular}{ccclll}
\hline Patron & Year & \multicolumn{1}{c}{ Status } & \multicolumn{1}{c}{ Place } & \multicolumn{1}{c}{ County } & \multicolumn{1}{c}{ Type } \\
\hline Prince Edward & 1537 & P. of Wales & Cambridge & Cambridge & Players \\
Prince Edward & 1537 & P. of Wales & Exeter & Devon & Players \\
Prince Edward & 1537 & P. of Wales & Plymouth & Devon & Players \\
Prince Edward & 1537 & P. of Wales & Ludlow & Shropshire & Minstrels
\end{tabular}


Table 3: Provincial Appearances of Prince Edward's Entertainers (cont'd)

\begin{tabular}{|c|c|c|c|c|c|}
\hline Patron & Year & Status & Place & County & Type \\
\hline Prince Edward & 1538 & P. of Wales & Cambridge & Cambridge & Players \\
\hline Prince Edward & 1538 & P. of Wales & Cambridge & Cambridge & Players \\
\hline Prince Edward & 1538 & P. of Wales & Bodmin & Cornwall & Minstrels \\
\hline Prince Edward & 1538 & P. of Wales & Plymouth & Devon & Players \\
\hline Prince Edward & 1538 & P. of Wales & Exeter & Devon & Minstrels \\
\hline Prince Edward & 1538 & P. of Wales & Southampton & Hampshire & Players \\
\hline Prince Edward & 1538 & P. of Wales & Canterbury & Kent & Players \\
\hline Prince Edward & 1538 & P. of Wales & Leicester & Leicester & Players \\
\hline Prince Edward & 1538 & P. of Wales & $\begin{array}{c}\text { Thetford } \\
\text { Priory }\end{array}$ & Norfolk & Players \\
\hline Prince Edward & 1538 & P. of Wales & Shrewsbury & Shropshire & Players \\
\hline Prince Edward & 1538 & P. of Wales & Rye & Sussex & Players \\
\hline Prince Edward & 1539 & P. of Wales & Cambridge & Cambridge & Players \\
\hline Prince Edward & 1539 & P. of Wales & Canterbury & Kent & Players \\
\hline Prince Edward & 1539 & P. of Wales & Faversham & Kent & Players \\
\hline Prince Edward & 1539 & P. of Wales & Sandwich & Kent & Players \\
\hline Prince Edward & 1539 & P. of Wales & Lydd & Kent & Minstrels \\
\hline Prince Edward & 1539 & P. of Wales & Lydd & Kent & Players \\
\hline Prince Edward & 1540 & P. of Wales & Bristol & Bristol & Players \\
\hline Prince Edward & 1540 & P. of Wales & Faversham & Kent & Players \\
\hline Prince Edward & 1540 & P. of Wales & Lydd & Kent & Players \\
\hline Prince Edward & 1540 & P. of Wales & New Romney & Kent & Players \\
\hline Prince Edward & 1540 & P. of Wales & Ludlow & Shropshire & Players \\
\hline Prince Edward & 1540 & P. of Wales & Ludlow & Shropshire & Players \\
\hline Prince Edward & 1540 & P. of Wales & Ludlow & Shropshire & Juggler \\
\hline Prince Edward & 1540 & P. of Wales & $\begin{array}{l}\text { Court } \\
\text { [Richmond] }\end{array}$ & Surrey & Players \\
\hline Prince Edward & 1540 & P. of Wales & Rye & Sussex & Players \\
\hline Prince Edward & 1540 & P. of Wales & Plymouth & Devon & Players \\
\hline Prince Edward & 1541 & P. of Wales & Bristol & Bristol & Players \\
\hline Prince Edward & 1541 & P. of Wales & Ludlow & Shropshire & Minstrels \\
\hline Prince Edward & 1541 & P. of Wales & Plymouth & Devon & Players \\
\hline Prince Edward & 1541 & P. of Wales & Lydd & Kent & Players \\
\hline Prince Edward & 1541 & P. of Wales & Dover & Kent & Players \\
\hline Prince Edward & 1541 & P. of Wales & Canterbury & Kent & Minstrels \\
\hline Prince Edward & 1541 & P. of Wales & Shrewsbury & Shropshire & Players \\
\hline
\end{tabular}


Table 3: Provincial Appearances of Prince Edward's Entertainers (cont'd)

\begin{tabular}{|c|c|c|c|c|c|}
\hline Patron & Year & Status & Place & County & Type \\
\hline Prince Edward & 1541 & P. of Wales & Shrewsbury & Shropshire & Players \\
\hline Prince Edward & 1541 & P. of Wales & Rye & Sussex & Players \\
\hline Prince Edward & 1541 & P. of Wales & Beverley & York & Players \\
\hline Prince Edward & 1542 & P. of Wales & Dover & Kent & Players \\
\hline Prince Edward & 1542 & P. of Wales & Folkestone & Kent & Players \\
\hline Prince Edward & 1542 & P. of Wales & $\begin{array}{c}\text { Belvoir } \\
\text { Castle }\end{array}$ & Leicester & Players \\
\hline Prince Edward & 1542 & P. of Wales & Norwich & Norfolk & Players \\
\hline Prince Edward & 1542 & P. of Wales & Rye & Sussex & Players \\
\hline Prince Edward & 1543 & P. of Wales & Bristol & Bristol & Bearward \\
\hline Prince Edward & 1543 & P. of Wales & Canterbury & Kent & Players \\
\hline Prince Edward & 1543 & P. of Wales & Dover & Kent & Players \\
\hline Prince Edward & 1543 & P. of Wales & Dover & Kent & Players \\
\hline Prince Edward & 1543 & P. of Wales & New Romney & Kent & Players \\
\hline Prince Edward & 1543 & P. of Wales & Dover & Kent & Bearward \\
\hline Prince Edward & 1543 & P. of Wales & New Romney & Kent & Minstrels \\
\hline Prince Edward & 1543 & P. of Wales & $\begin{array}{l}\text { Great } \\
\text { Yarmouth }\end{array}$ & Norfolk & Players \\
\hline Prince Edward & 1543 & P. of Wales & Norwich & Norfolk & Players \\
\hline Prince Edward & 1543 & P. of Wales & Norwich & Norfolk & Players \\
\hline Prince Edward & 1543 & P. of Wales & Ludlow & Shropshire & Bearward \\
\hline Prince Edward & 1543 & P. of Wales & Chicester & Sussex & Juggler \\
\hline Prince Edward & 1544 & P. of Wales & Cambridge & Cambridge & Players \\
\hline Prince Edward & 1544 & P. of Wales & Barnstaple & Devon & Players \\
\hline Prince Edward & 1544 & P. of Wales & Plymouth & Devon & Players \\
\hline Prince Edward & 1544 & P. of Wales & Canterbury & Kent & Players \\
\hline Prince Edward & 1544 & P. of Wales & Dover & Kent & Players \\
\hline Prince Edward & 1544 & P. of Wales & Dover & Kent & Players \\
\hline Prince Edward & 1544 & P. of Wales & Folkestone & Kent & Players \\
\hline Prince Edward & 1544 & P. of Wales & New Romney & Kent & Players \\
\hline Prince Edward & 1544 & P. of Wales & New Romney & Kent & Players \\
\hline Prince Edward & 1544 & P. of Wales & Folkestone & Kent & Bearward \\
\hline Prince Edward & 1544 & P. of Wales & New Romney & Kent & Bearward \\
\hline Prince Edward & 1544 & P. of Wales & New Romney & Kent & Minstrells \\
\hline Prince Edward & 1544 & P. of Wales & Chichester & Sussex & Players \\
\hline Prince Edward & 1544 & P. of Wales & Rye & Sussex & Players \\
\hline
\end{tabular}


Table 3: Provincial Appearances of Prince Edward's Entertainers (cont'd)

\begin{tabular}{ccllll}
\hline Patron & \multicolumn{1}{c}{ Year } & \multicolumn{1}{c}{ Status } & \multicolumn{1}{c}{ Place } & \multicolumn{1}{c}{ County } & \multicolumn{1}{c}{ Type } \\
\hline Prince Edward & 1544 & P. of Wales & Rye & Sussex & Players \\
Prince Edward & 1544 & P. of Wales & Rye & Sussex & Players \\
Prince Edward & 1544 & P. of Wales & Chicester & Sussex & Bearward \\
Prince Edward & 1544 & P. of Wales & Rye & Sussex & Bearward \\
Prince Edward & 1545 & P. of Wales & New Romney & Kent & Players \\
Prince Edward & 1545 & P. of Wales & Folkestone & Kent & Minstrels \\
Prince Edward & 1545 & P. of Wales & Norwich & Norfolk & Players \\
Prince Edward & 1545 & P. of Wales & Rye & Sussex & Players \\
Prince Edward & 1546 & P. of Wales & Canterbury & Kent & Players \\
Prince Edward & 1546 & P. of Wales & Norwich & Norfolk & Players \\
Prince Edward & 1546 & P. of Wales & Rye & Sussex & Players \\
Prince Edward & 1547 & succeeded & & & \\
\hline
\end{tabular}

Prince Edward's performers appear in provincial records right after his birth. In 1537 payments to the prince's entertainers are listed in accounts from Cambridge, Exeter, and Plymouth. ${ }^{75}$ Sources published to date record several tours by the prince's performers every year afterwards. Perhaps as one means of publicizing his birth and status, in 1538 his entertainers appear eleven times in records from nine different counties (Cambridge, Cornwall, Devon, Hampshire, Kent, Leicester, Norfolk, Shropshire, and Sussex). ${ }^{76}$ In the next four years (1539-42) his performers appear thirty-two times in records from court (at Richmond in Surrey) and nine other counties (Bristol, Cambridge, Devon, Kent, Leicester, Norfolk, Shropshire, Sussex, and York). ${ }^{77}$

Three events relating to the six-year-old Edward occurred in 1543-4). His official household and court were established; by the terms of the Treaty of Greenwich, he was betrothed to the infant Queen Mary of Scotland, and a third Act of Succession specifically named him as Henry's primary heir. ${ }^{78}$ May it be more than coincidence that there are thirty references to his performers playing in the provinces? In those two years his entertainers represented his status in counties Bristol, Cambridge, Devon, Kent, Norfolk, Shropshire, and Sussex, ${ }^{79}$ appearing almost as many times away from his court as they had in the previous four years. The prince's performers continued to appear in provincial records from Kent, Norfolk, and Sussex every year after 1544 until his succession in $1547 .^{80}$ In sum, provincial accounts 
published to date show eighty-three appearances by Prince Edward's entertainers in twelve different counties, an average of eight per year.

This data seems to reveal a pattern. Specific details about Henry's queens' and Henry's children's troupes of players are sparse. Yet the pattern revealed in the provincial records strongly suggests that as queens came and went, troupes of performers were passed from one queen to her successor, and that as Henry's possibilities for a successor shifted from offspring to offspring, a troupe of entertainers toured the counties sporting the livery and/or badges of the presumptive heir of the moment. To recap, Queen Katherine of Aragon's troupe disappeared in provincial records 1531, the year Henry sent her away from court, and Queen Anne Boleyn's troupe, which appears in the year she became Henry's wife and queen, seems to have been Katherine's, augmented by players from the troupe of the now bastardized Princess Mary. Queen Anne's troupe disappears in 1536, the year she was executed, and Queen Jane Seymour appears to have taken over Anne's entertainers along with the rest of the queen's household. Queen Catherine Howard's troupe appears shortly after her marriage to Henry in 1540, and disappears by 1542, the year of her execution. Queen Catherine Parr's troupe appears in the year of her marriage, 1543, and tours until 1547, the year of Henry's death. Princess Mary's troupe appears the year she becomes de facto princess of Wales (1529), and disappears in 1533 when she is bastardized. Henry Fitzroy becomes duke of Richmond in 1525, and by 1527, when it was apparent Queen Catherine would produce no more children, the duke of Richmond's entertainers appear in provincial records. They disappear in 1534, shortly after Princess Elizabeth's birth, but his bearward reappears in 1536, the year of Elizabeth's bastardization. Prince Edward is born in 1537, and almost immediately performers tour England under his name. The scanty information we possess about the personnel of these other royal troupes suggests King Henry gave his support and prestige to his wives' and children's entertainment troupes. John Slye moved from Henry's personal troupe to Princess Mary's, to Anne Boleyn's, to Jane Seymour's; his brother William Slye moved from Henry's troupe to Mary's, to Anne Boleyn's. John Young moved from Henry's troupe to Jane Seymour's, and then to Prince Edward's troupe. ${ }^{81}$

The pattern sketched above suggests the answer to the question posed in my title — 'Did Henry VIII's Queens and Children Patronize Travelling Performers?' - is yes they did. There are two glaring exceptions to this pattern; records to date show that neither Queen Anne of Cleves nor Princess Elizabeth was ever named as a patron of performers. But these exceptions, I 
believe, prove the rule. Henry expected a male heir from Anne Boleyn after Elizabeth's birth, and with Anne's downfall less than three years later, Elizabeth was bastardized. As for Anne of Cleves, from the time Henry first laid eyes on Anne, he was determined to be rid of her. ${ }^{82}$

As Leonard Tennenhouse writes: 'we have to consider the drama as a forum for staging symbolic shows of state power and as a vehicle for disseminating court ideology', 83 and by Elizabeth's reign, touring players were a form of 'power on display', indicating favour and status. ${ }^{84}$ For Anne of Cleves, and for Princess Elizabeth, who, after all, was named in Henry's will as his last choice as a successor, there was no imperative to advertise or bestow status and legitimacy on them.

\section{Appendix: Provincial Appearances of Entertainers of Queens and Heirs of Edward IV, Richard III, and Henry VII}

Table 4: Queens of Edward IV, Richard III, and Henry VII ${ }^{85}$

\begin{tabular}{lllll}
\hline \multicolumn{1}{c}{ Patron } & \multicolumn{1}{c}{ Year } & \multicolumn{1}{c}{ Place } & \multicolumn{1}{c}{ County } & \multicolumn{1}{c}{ Type } \\
\hline Elizabeth Woodville & 1464 & Worcester & Worcester & Minstrels \\
Elizabeth Woodville & 1467 & Barnstaple & Devon & Minstrels \\
Elizabeth Woodville & 1470 & Dover & Kent & Minstrels \\
Elizabeth Woodville & 1473 & Shrewsbury & Shropshire & Players \\
Elizabeth Woodville & 1473 & Worcester & Worcester & Players \\
Elizabeth Woodville & 1474 & Barnstaple & Devon & Minstrels \\
Elizabeth Woodville & 1475 & Canterbury & Kent & Minstrels \\
Elizabeth Woodville & 1476 & Dover & Kent & Minstrels \\
Elizabeth Woodville & 1476 & Canterbury & Kent & Minstrels \\
Elizabeth Woodville & 1476 & Lydd & Kent & Minstrels \\
Elizabeth Woodville & 1476 & Shrewsbury & Shropshire & Minstrels \\
Elizabeth Woodville & 1477 & Canterbury & Kent & Players \\
Elizabeth Woodville & 1477 & New Romney & Kent & Players \\
Elizabeth Woodville & 1477 & Shrewsbury & Shropshire & Minstrels \\
Elizabeth Woodville & 1477 & Rye & Sussex & Minstrels \\
Elizabeth Woodville & 1478 & Canterbury & Kent & Players \\
Elizabeth Woodville & 1478 & New Romney & Kent & Players \\
Elizabeth Woodville & 1478 & Worcester & Worcester & Players \\
Elizabeth Woodville & 1478 & Lydd & Kent & Minstrels \\
Elizabeth Woodville & 1479 & New Romney & Kent & Players
\end{tabular}


Table 4: Queens of Edward IV, Richard III, and Henry VII ${ }^{85}$ (cont'd)

\begin{tabular}{|c|c|c|c|c|}
\hline Patron & Year & Place & County & Type \\
\hline Elizabeth Woodville & 1479 & Lydd & Kent & Players \\
\hline Elizabeth Woodville & 1479 & Sandwich & Kent & Minstrels \\
\hline Elizabeth Woodville & 1479 & Hythe & Kent & Minstrels \\
\hline Elizabeth Woodville & 1480 & Canterbury & Kent & Players \\
\hline Elizabeth Woodville & 1480 & New Romney & Kent & Players \\
\hline Elizabeth Woodville & 1480 & Dover & Kent & Minstrels \\
\hline Elizabeth Woodville & 1480 & Rye & Sussex & Minstrels \\
\hline Elizabeth Woodville & 1481 & New Romney & Kent & Players \\
\hline Elizabeth Woodville & 1481 & New Romney & Kent & Players \\
\hline Elizabeth Woodville & 1481 & Dover & Kent & Minstrels \\
\hline Elizabeth Woodville & 1481 & Canterbury & Kent & Minstrels \\
\hline Elizabeth Woodville & 1481 & Rye & Sussex & Minstrels \\
\hline Elizabeth Woodville & 1481 & New Romney & Kent & Minstrels \\
\hline Elizabeth Woodville & 1482 & Canterbury & Kent & Players \\
\hline Elizabeth Woodville & 1482 & Lydd & Kent & Players \\
\hline Elizabeth Woodville & 1482 & New Romney & Kent & Players \\
\hline Elizabeth Woodville & 1482 & Rye & Sussex & Minstrels \\
\hline Elizabeth Woodville & $1482 ?$ & Battle Abbey & Sussex & Players \\
\hline Elizabeth Woodville & 1483 & widowed & & \\
\hline Anne Neville & 1483 & Canterbury & Kent & Players \\
\hline Anne Neville & 1483 & Hythe & Kent & Minstrels \\
\hline Anne Neville & 1483 & Dover & Kent & Minstrels \\
\hline Anne Neville & 1483 & Cambridge & Cambridge & Players \\
\hline Anne Neville & 1484 & Hythe & Kent & Minstrels \\
\hline Anne Neville & 1484 & New Romney & Kent & Minstrels \\
\hline Anne Neville & 1484 & Lydd & Kent & Players \\
\hline Anne Neville & 1484 & died & & \\
\hline Elizabeth York & 1486 & Canterbury & Kent & Players \\
\hline Elizabeth York & 1486 & Hythe & Kent & Minstrels \\
\hline Elizabeth York & 1486 & Dover & Kent & Minstrels \\
\hline Elizabeth York & 1486 & New Romney & Kent & Minstrels \\
\hline Elizabeth York & 1486 & New Romney & Kent & Minstrels \\
\hline Elizabeth York & 1487 & Canterbury & Kent & Players \\
\hline Elizabeth York & 1487 & Dover & Kent & Minstrels \\
\hline
\end{tabular}


Table 4: Queens of Edward IV, Richard III, and Henry VII ${ }^{85}$ (cont'd)

\begin{tabular}{|c|c|c|c|c|}
\hline Patron & Year & Place & County & Type \\
\hline Elizabeth York & 1487 & New Romney & Kent & Minstrels \\
\hline Elizabeth York & 1487 & Rye & Sussex & Minstrels \\
\hline Elizabeth York & 1488 & Dover & Kent & Minstrels \\
\hline Elizabeth York & 1488 & Rye & Sussex & Minstrels \\
\hline Elizabeth York & 1490 & Canterbury & Kent & Players \\
\hline Elizabeth York & 1490 & Hythe & Kent & Minstrels \\
\hline Elizabeth York & 1491 & Cambridge & Cambridge & Players \\
\hline Elizabeth York & 1491 & Dover & Kent & Minstrels \\
\hline Elizabeth York & 1491 & Rye & Sussex & Minstrels \\
\hline Elizabeth York & 1493 & Canterbury & Kent & Players \\
\hline Elizabeth York & 1493 & Shrewsbury & Shropshire & Players \\
\hline Elizabeth York & 1493 & Shrewsbury & Shropshire & Players \\
\hline Elizabeth York & 1493 & Hythe & Kent & Minstrels \\
\hline Elizabeth York & 1494 & Dover & Kent & Minstrels \\
\hline Elizabeth York & 1494 & New Romney & Kent & Minstrels \\
\hline Elizabeth York & 1495 & Canterbury & Kent & Players \\
\hline Elizabeth York & 1495 & Hythe & Kent & Minstrels \\
\hline Elizabeth York & 1495 & Shrewsbury & Shropshire & Minstrels \\
\hline Elizabeth York & 1496 & New Romney & Kent & Minstrels \\
\hline Elizabeth York & 1497 & Canterbury & Kent & Players \\
\hline Elizabeth York & 1497 & Sandwich & Kent & Minstrels \\
\hline Elizabeth York & 1498 & Cambridge & Cambridge & Players \\
\hline Elizabeth York & 1498 & Canterbury & Kent & Players \\
\hline Elizabeth York & 1498 & Hythe & Kent & Minstrels \\
\hline Elizabeth York & 1498 & Dover & Kent & Minstrels \\
\hline Elizabeth York & 1498 & New Romney & Kent & Minstrels \\
\hline Elizabeth York & 1498 & Sandwich & Kent & Minstrels \\
\hline Elizabeth York & 1498 & Rye & Sussex & Minstrels \\
\hline Elizabeth York & 1499 & Canterbury & Kent & Players \\
\hline Elizabeth York & 1499 & Hythe & Kent & Minstrels \\
\hline Elizabeth York & 1499 & Dover & Kent & Minstrels \\
\hline Elizabeth York & 1499 & New Romney & Kent & Minstrels \\
\hline Elizabeth York & 1500 & Cambridge & Cambridge & Players \\
\hline Elizabeth York & 1500 & Canterbury & Kent & Players \\
\hline
\end{tabular}


Table 4: Queens of Edward IV, Richard III, and Henry VII ${ }^{85}$ (cont'd)

\begin{tabular}{rrlll}
\hline Patron & Year & \multicolumn{1}{c}{ Place } & \multicolumn{1}{c}{ County } & \multicolumn{1}{c}{ Type } \\
\hline Elizabeth York & 1500 & Wells & Somerset & Players \\
Elizabeth York & 1500 & Dover & Kent & Minstrels \\
Elizabeth York & 1500 & Canterbury & Kent & Minstrels \\
Elizabeth York & 1501 & Canterbury & Kent & Minstrels \\
Elizabeth York & 1502 & Canterbury & Kent & Players \\
Elizabeth York & 1502 & Wells & Somerset & Players \\
Elizabeth York & $\mathbf{1 5 0 3}$ & died & & \\
\hline
\end{tabular}

Table 5: Heirs of Edward IV, Richard III, and Henry VII ${ }^{86}$

\begin{tabular}{llllll}
\hline \multicolumn{1}{c}{ Patron } & \multicolumn{1}{c}{ Year } & \multicolumn{1}{c}{ Status } & \multicolumn{1}{c}{ Place } & \multicolumn{1}{c}{ County } & \multicolumn{1}{c}{ Type } \\
\hline Edward Plantagenet & pre-1483 & P. Wales & Selby Abbey & York & Players \\
Edward Plantagenet & 1473 & P. Wales & Shrewsbury & Shropshire & Minstrels \\
Edward Plantagenet & 1473 & P. Wales & Worcester & Worcester & Minstrels \\
Edward Plantagenet & 1474 & P. Wales & Shrewsbury & Shropshire & Minstrels \\
Edward Plantagenet & 1474 & P. Wales & Barnstaple & Devon & Minstrels \\
Edward Plantagenet & 1475 & P. Wales & Barnstaple & Devon & Minstrels \\
Edward Plantagenet & 1476 & P. Wales & New Romney & Kent & Players \\
Edward Plantagenet & 1476 & P. Wales & New Romney & Kent & Minstrels \\
Edward Plantagenet & 1477 & P. Wales & Launceton & Cornwall & Bearward \\
Edward Plantagenet & 1477 & P. Wales & Dover & Kent & Minstrels \\
Edward Plantagenet & 1477 & P. Wales & Hythe & Kent & Minstrels \\
Edward Plantagenet & 1478 & P. Wales & Barnstaple & Devon & Players \\
Edward Plantagenet & 1478 & P. Wales & Worcester & Worcester & Players \\
Edward Plantagenet & 1478 & P. Wales & Dover & Kent & Minstrels \\
Edward Plantagenet & 1478 & P. Wales & Barnstaple & Devon & Minstrels \\
Edward Plantagenet & 1478 & P. Wales & Worcester & Worcester & Minstrels \\
Edward Plantagenet & 1479 & P. Wales & Canterbury & Kent & Players \\
Edward Plantagenet & 1479 & P. Wales & New College & Oxford & Players \\
Edward Plantagenet & 1479 & P. Wales & New Romney & Kent & Players \\
Edward Plantagenet & 1479 & P. Wales & Lyd & Kent & Players \\
Edward Plantagenet & 1479 & P. Wales & Shrewsbury & Shropshire & Minstrels \\
Edward Plantagenet & 1479 & P. Wales & Canterbury & Kent & Minstrels \\
Edward Plantagenet & 1479 & P. Wales & New College & Oxford & Minstrels \\
Edward Plantagenet & 1480 & P. Wales & New Romney & Kent & Players
\end{tabular}


Table 5: Heirs of Edward IV, Richard III, and Henry VII ${ }^{86}$ (cont'd)

\begin{tabular}{|c|c|c|c|c|c|}
\hline Patron & Year & Status & Place & County & Type \\
\hline Edward Plantagenet & 1480 & P. Wales & Dover & Kent & Minstrels \\
\hline Edward Plantagenet & 1481 & P. Wales & Canterbury & Kent & Players \\
\hline Edward Plantagenet & 1481 & P. Wales & Hythe & Kent & Minstrels \\
\hline Edward Plantagenet & 1482 & P. Wales & Battle Abbey & Sussex & Players \\
\hline Edward Plantagenet & 1482 & P. Wales & Worcester & Worcester & Minstrels \\
\hline Edward Plantagenet & 1483 & $\begin{array}{l}\text { succeeded/ } \\
\text { died? }\end{array}$ & & & \\
\hline Richard Plantagenet & 1477 & D. York & Shrewsbury & Shropshire & Minstrels \\
\hline Richard Plantagenet & 1481 & D. York & Canterbury & Kent & Players \\
\hline Richard Plantagenet & 1481 & D. York & Worcester & Worcester & Minstrels \\
\hline Richard Plantagenet & 1482 & D. York & Rye & Sussex & Minstrels \\
\hline Richard Plantagenet & 1483 & died? & & & \\
\hline Edward son of R. III & 1483 & P. Wales & Cambridge & Cambridge & Players \\
\hline Edward son of R. III & 1484 & died & & & \\
\hline Arthur Tudor & 1487 & P. Wales & New Romney & Kent & Minstrels \\
\hline Arthur Tudor & 1488 & P. Wales & Rye & Sussex & Minstrels \\
\hline Arthur Tudor & 1488 & P. Wales & King's College & Cambridge & Pipers \\
\hline Arthur Tudor & 1489 & P. Wales & Dover & Kent & Minstrels \\
\hline Arthur Tudor & 1489 & P. Wales & Sandwich & Kent & Minstrels \\
\hline Arthur Tudor & 1489 & P. Wales & New Romney & Kent & Minstrels \\
\hline Arthur Tudor & 1490 & P. Wales & Canterbury & Kent & Players \\
\hline Arthur Tudor & 1490 & P. Wales & Rye & Sussex & Minstrels \\
\hline Arthur Tudor & 1490 & P. Wales & Dover & Kent & Minstrels \\
\hline Arthur Tudor & 1491 & P. Wales & Dover & Kent & Minstrels \\
\hline Arthur Tudor & 1493 & P. Wales & Cambridge & Cambridge & Players \\
\hline Arthur Tudor & 1493 & P. Wales & New Romney & Kent & $\begin{array}{r}\text { Baboon } \\
\text { keeper }\end{array}$ \\
\hline Arthur Tudor & 1493 & P. Wales & Rye & Sussex & Minstrels \\
\hline Arthur Tudor & 1494 & P. Wales & Dover & Kent & Players \\
\hline Arthur Tudor & 1494 & P. Wales & New Romney & Kent & Players \\
\hline Arthur Tudor & 1494 & P. Wales & Rye & Sussex & Players \\
\hline Arthur Tudor & 1494 & P. Wales & Shrewsbury & Shropshire & Players \\
\hline Arthur Tudor & 1494 & P. Wales & New Romney & Kent & Minstrels \\
\hline Arthur Tudor & 1495 & P. Wales & Canterbury & Kent & Players \\
\hline Arthur Tudor & 1495 & P. Wales & Dover & Kent & Minstrels \\
\hline
\end{tabular}


Table 5: Heirs of Edward IV, Richard III, and Henry VII ${ }^{86}$ (cont'd)

\begin{tabular}{|c|c|c|c|c|c|}
\hline Patron & Year & Status & Place & County & Type \\
\hline Arthur Tudor & 1495 & P. Wales & New Romney & Kent & Minstrels \\
\hline Arthur Tudor & 1496 & P. Wales & Rye & Sussex & Minstrels \\
\hline Arthur Tudor & 1497 & P. Wales & Sandwich & Kent & Minstrels \\
\hline Arthur Tudor & 1498 & P. Wales & Cambridge & Cambridge & Players \\
\hline Arthur Tudor & 1498 & P. Wales & London & London & Players \\
\hline Arthur Tudor & 1498 & P. Wales & Thetford Priory & Norfolk & Players \\
\hline Arthur Tudor & 1498 & P. Wales & Rye & Sussex & Minstrels \\
\hline Arthur Tudor & 1498 & P. Wales & Rye & Sussex & Minstrels \\
\hline Arthur Tudor & 1498 & P. Wales & Dover & Kent & Minstrels \\
\hline Arthur Tudor & 1499 & P. Wales & Court & Middlesex & Players \\
\hline Arthur Tudor & 1499 & P. Wales & Cambridge & Cambridge & Players \\
\hline Arthur Tudor & 1499 & P. Wales & Grimsby & Lincoln & Minstrels \\
\hline Arthur Tudor & 1499 & P. Wales & York & York & Minstrels \\
\hline Arthur Tudor & 1500 & P. Wales & Selby Abbey & York & Players \\
\hline Arthur Tudor & 1500 & P. Wales & Thetford Priory & Norfolk & Players \\
\hline Arthur Tudor & 1500 & P. Wales & Wells & Somerset & Players \\
\hline Arthur Tudor & 1500 & P. Wales & Canterbury & Kent & Minstrels \\
\hline Arthur Tudor & 1501 & P. Wales & Court & Middlesex & Players \\
\hline Arthur Tudor & 1501 & P. Wales & Canterbury & Kent & Minstrels \\
\hline Arthur Tudor & 1502 & died & & & \\
\hline Henry Tudor & 1496 & D. York & Hythe & Kent & Minstrels \\
\hline Henry Tudor & 1496 & D. York & New Romney & Kent & Minstrels \\
\hline Henry Tudor & 1497 & D. York & Rye & Sussex & Bearward \\
\hline Henry Tudor & 1499 & D. York & Battle Abbey & Sussex & Players \\
\hline Henry Tudor & 1499 & D. York & Rye & Sussex & Minstrels \\
\hline Henry Tudor & 1499 & D. York & Rye & Sussex & Minstrels \\
\hline Henry Tudor & 1499 & D. York & Hythe & Kent & Minstrels \\
\hline Henry Tudor & 1502 & P. Wales & Plymouth & Devon & Minstrels \\
\hline Henry Tudor & 1502 & P. Wales & Court & Middlesex & Players \\
\hline Henry Tudor & 1503 & P. Wales & Court & Middlesex & Players \\
\hline Henry Tudor & 1503 & P. Wales & Cambridge & Cambridge & Players \\
\hline Henry Tudor & 1503 & P. Wales & Cambridge & Cambridge & Players \\
\hline Henry Tudor & 1503 & P. Wales & Thetford Priory & Norfolk & Players \\
\hline Henry Tudor & 1503 & P. Wales & Rye & Sussex & Bearward \\
\hline
\end{tabular}


Table 5: Heirs of Edward IV, Richard III, and Henry VII ${ }^{86}$ (cont'd)

\begin{tabular}{|c|c|c|c|c|c|}
\hline Patron & Year & Status & Place & County & Type \\
\hline Henry Tudor & 1503 & P. Wales & Dover & Kent & Minstrels \\
\hline Henry Tudor & 1503 & P. Wales & Hythe & Kent & Minstrels \\
\hline Henry Tudor & 1504 & P. Wales & Court & Middlesex & Players \\
\hline Henry Tudor & 1504 & P. Wales & Thetford Priory & Norfolk & Players \\
\hline Henry Tudor & 1504 & P. Wales & Rye & Sussex & Bearward \\
\hline Henry Tudor & 1504 & P. Wales & Dover & Kent & Bearward \\
\hline Henry Tudor & 1504 & P. Wales & Dover & Kent & Minstrels \\
\hline Henry Tudor & 1504 & P. Wales & Canterbury & Kent & Minstrels \\
\hline Henry Tudor & 1504 & P. Wales & Rye & Sussex & Minstrels \\
\hline Henry Tudor & 1505 & P. Wales & Court & Middlesex & Players \\
\hline Henry Tudor & 1505 & P. Wales & Wells & Somerset & Players \\
\hline Henry Tudor & 1505 & P. Wales & Dover & Kent & Minstrels \\
\hline Henry Tudor & 1505 & P. Wales & Plymouth & Devon & Minstrels \\
\hline Henry Tudor & 1505 & P. Wales & Hythe & Kent & Minstrels \\
\hline Henry Tudor & 1505 & P. Wales & Rye & Sussex & Minstrels \\
\hline Henry Tudor & 1505 & P. Wales & Rye & Sussex & Minstrels \\
\hline Henry Tudor & 1505 & P. Wales & Canterbury & Kent & Minstrels \\
\hline Henry Tudor & 1506 & P. Wales & Canterbury & Kent & Players \\
\hline Henry Tudor & 1506 & P. Wales & Thetford Priory & Norfolk & Players \\
\hline Henry Tudor & 1506 & P. Wales & Rye & Sussex & Bearward \\
\hline Henry Tudor & 1506 & P. Wales & Dover & Kent & Minstrels \\
\hline Henry Tudor & 1506 & P. Wales & New Romney & Kent & Minstrels \\
\hline Henry Tudor & 1506 & P. Wales & Hythe & Kent & Minstrels \\
\hline Henry Tudor & 1506 & P. Wales & York & York & Minstrels \\
\hline Henry Tudor & 1506 & P. Wales & Rye & Sussex & Minstrels \\
\hline Henry Tudor & 1506 & P. Wales & Rye & Sussex & Minstrels \\
\hline Henry Tudor & 1506 & P. Wales & Rye & Sussex & Minstrels \\
\hline Henry Tudor & 1507 & P. Wales & Dover & Kent & Minstrels \\
\hline Henry Tudor & 1507 & P. Wales & Dover & Kent & Minstrels \\
\hline Henry Tudor & 1507 & P. Wales & Dover & Kent & Minstrels \\
\hline Henry Tudor & 1507 & P. Wales & Hythe & Kent & Minstrels \\
\hline Henry Tudor & 1507 & P. Wales & New Romney & Kent & Minstrels \\
\hline Henry Tudor & 1507 & P. Wales & Rye & Sussex & Minstrels \\
\hline Henry Tudor & 1507 & P. Wales & Canterbury & Kent & Minstrels \\
\hline
\end{tabular}


Table 5: Heirs of Edward IV, Richard III, and Henry VII ${ }^{86}$ (cont'd)

\begin{tabular}{llllll}
\hline Patron & Year & \multicolumn{1}{c}{ Status } & \multicolumn{1}{c}{ Place } & \multicolumn{1}{c}{ County } & \multicolumn{1}{c}{ Type } \\
\hline Henry Tudor & 1507 & P. Wales & Sandwich & Kent & Minstrels \\
Henry Tudor & 1508 & P. Wales & Battle Abbey & Sussex & Players \\
Henry Tudor & 1508 & P. Wales & Rye & Sussex & Bearward \\
Henry Tudor & 1508 & P. Wales & Dover & Kent & Minstrels \\
Henry Tudor & 1508 & P. Wales & Dover & Kent & Minstrels \\
Henry Tudor & 1508 & P. Wales & York & York & Minstrels \\
Henry Tudor & 1508 & P. Wales & Rye & Sussex & Minstrels \\
Henry Tudor & 1508 & P. Wales & Rye & Sussex & Minstrels \\
Henry Tudor & 1509 & P. Wales & Canterbury & Kent & Players \\
Henry Tudor & $\mathbf{1 5 0 9}$ & succeeded & & & \\
\hline
\end{tabular}

\section{Notes}

1 Ian Lancashire, Dramatic Texts and Records of Britain...to 1558 (Toronto, 1984); David Galloway and John Wasson (eds), Records of Plays and Players in Norfolk and Suffolk, Malone Society Publication (Oxford, 1980).

2 Counties: Cheshire, Cornwall, Cumberland, Devon, Dorset, Gloucestershire, Herefordshire, Kent, Lancashire, Lincolnshire, Middlesex, Shropshire, Somerset, Sussex, Westmorland, Worcestershire. Municipalities: Bristol, Cambridge, Chester, Coventry, London (ecclesiastical sites), Newcastle upon Tyne, Norwich, Oxford, York. The Malone Society volume provides the only collection of dramatic records published to date for Norfolk and Suffolk. Lancashire's Dramatic Texts and Records and a few other sources offer some dramatic records from the following counties for which there are as yet no ReED volumes: Bedford, Berkshire, Buckingham, Derby, Durham, Essex, Hampshire, Hertford, Leicester, Northampton, Northumberland, Nottingham, Stafford, Surrey, Warwick, and Wiltshire.

3 Galloway and Wasson, Norfolk and Suffolk, 18, 188; James M. Gibson (ed.), REED: Kent, Diocese of Canterbury (Toronto, 2002), 1.53, 2.417. For several years I assigned REED volumes to students in my senior and graduate level medieval and early modern history and theatre history courses. Students appreciated the historical backgrounds and discussions of performance activities, but consistently they asked, 'what do I do with all the data?'

4 See http://link.library.utoronto.ca/reed/index.cfm. 
5 James H. Forse, 'The Flow and Ebb of Amateur Touring Troupes in Tudor England', Shakespeare and Renaissance Association Selected Papers 22 (1999); 'Secularizing the Saint: The Journey of St. George from Feast Day to Horse Race', Popular Culture Review 16 (2005); 'Getting Your Name Out There: Traveling Acting Companies and Aristocratic Prestige in Tudor England', Quidditas 26 and 27 (2005 and 2006), http://humanities.byu.edu/rmmra; 'Pleasing the Queen but Preserving Our Past: Cheshire and Lincolnshire Attempt to Continue Their Cycle Plays and Satisfy Elizabeth's Injunctions', Popular Culture Review 18 (2007).

6 David Dymond (ed.), The Register of Thetford Priory (Oxford, 1995); Extracts from the Account Rolls of the Abbey of Durham (Durham, 1898-1901).

7 Gibson, REED Kent, 1.28.

8 I use the terms 'entertainers' or 'performers' to cover a variety of activities offered by servants whose primary purpose was entertainment. Until records began to be written in English rather than Latin (ca 1525), records use the terms histriones, mimis, luditores, and lusitores. Histriones and mimi most likely designate 'actors' of some sort, and luditores and lusitores are generic terms for 'players'. See William Smith, A Smaller Latin-English Dictionary, rev. ed., J.F. Lockwood (New York, 1962), 311, 410-11, 435. Performers designated as minstrels may be actors, musicians, dancers, or all of these. Entertainers such as bearwards, keepers of animals in the royal menageries, jugglers, jesters, usually are specified, and musicians often are identified as trumpeters, pipers, harpists, drummers, and waits.

9 Gibson, REED: Kent, 1.28, 31.

10 Leonard Tennenhouse, Power on Display (New York, 1986), 39.

11 Records from Exeter (1533) note 6s 8d paid to King Henry VIII's minstrels 'that brought the letters to Master Mayor' (John M. Wasson [ed.], REED: Devon [Toronto, 1986], 132). Records from Canterbury (1340) and Battle Abbey (1346) list payments to messengers and entertainers of Prince Edward of Woodstock (the 'Black Prince'), his father Edward III, his mother Phillipa of Hainault, and other nobles (Gibson, REED: Kent, 1.41; Lewis, REED: Sussex, 182). I think it probable that the messengers also were the entertainers. See Scott McMillin and Sally-Beth MacLean The Queen's Men and Their Plays (Cambridge, 1998), 22-32; Sally-Beth McLean, 'The Politics of Patronage: Dramatic Records in Robert Dudley's Household Books', Shakespeare Quarterly 44 (1993), 175-82. DOI: http://dx.doi.org/10.2307/2871138: Forse, 'Getting Your Name Out There', 118-19.

12 The following citations are a sampling of performance events by royal troupes in Kent. A full listing would be very long, numbering in the hundreds - for instance, King Henry VI's performers appear fifty times in Kentish records, Queen Elizabeth's over 120 times. Gibson, REED: Kent, 1.28, 31, 34, 39-42, 51-9, 83-5, 86, 
90-7, 103-09, 124, 135, 138, 140, 142, 145, 147-8, 150, 153-4, 156, 168, 218-21, 271-7; REED: Kent, 2.388-90, 410, 417, 425, 430, 433-4, 437, 440-1, 494, 543, 576, 606-12, 653-69, 679, 681, 684, 689, 691-2, 740, 742-3, 764, 768, 773-4, $824,827,836,838,849-51$.

13 The 1400 s records (to date) detail touring by performers of the following lords warden: Humphrey duke of Gloucester, lord protector, James Fiennes Baron Saye, Humphrey Stafford duke of Buckingham, Richard Neville earl of Warwick, William Fitz Alan earl of Arundel, Henry prince of Wales (future Henry VIII). See Gibson, REED: Kent, 1.64, 72, 198; REED: Kent, 2.320-5, 328-30, 334-46, 348, 350-2, 354-7, 359-71, 736; and Cameron Lewis (ed.), REED: Sussex, 44-57, 68-9, $184-6$.

14 Henry Brooke Baron Cobham, the last lord warden of the 1500s, was the sole lord warden to have no performers on tour in Kent and Sussex. Records (to date) show extensive touring by performers attached to his predecessors: Henry prince of Wales (future Henry VIII), Sir Edward Poynings, Sir Edward Guildford, George Boleyn Viscount Rocheford, Henry Fitzroy duke of Richmond, Arthur Plantagent Viscount Lisle, Sir Thomas Cheyne, and William Brooke Baron Cobham. See Gibson, REED: Kent 1.99-103, 156, 158, 170-3, 181, 197-8; REED: Kent, 2. 387, 389-95, 398-401, 405-6, 408, 410-11, 413, 416-7, 422, 424-6, 436-8, 440-58, 467-9, $484,486,526,540,543-6,551,557,575-81,590,612-21,624-9,673-6,681-95$, 699, 757-79, 782, 299, 832-5, 837-8, 846, 849-51; and Lewis, REED: Sussex, 70-7, 79-83, 86-7, 90-2, 95-9, 136.

15 Maurice Powicke, The Thirteenth Century, 1216-1307 (New York, 1962), 187-207; Patricia Hyde and Michael Zell, 'Governing the County', Michael Zell (ed.), Early Modern Kent (Woodbridge, 2000), 7-21, 24-5; P.J.P. Goldberg, Medieval England 1250-1550: A Social History (New York, 2004), see chapter 13 for the Peasants' Revolt. Also see: M. Bohna, 'Armed force and civic legitimacy in Jack Cade's revolt, 1450', English Historical Review 118 (2003), 563-82, and Charles Ross, Richard III (Berkeley, 1981), 105-19.

16 Gibson, REED: Kent, 1.147, 158; REED: Kent, 2.445, 447, 671; Alan H. Nelson (ed.), REED: Cambridge (Toronto, 1989), 1.30, 131; Wasson, REED: Devon, 132; Mark C. Pilkinton (ed.), REED: Bristol (Toronto, 1997), 57; David N. Klausner (ed.), REED: Herefordshire, Worcestershire (Toronto, 1990), 530, 626; Thetford Priory, 576.

17 Pilkinton, REED: Bristol, 42, 50-1; Nelson, REED: Cambridge, 1.106, 144; Klausner, REED: Hereford/Worcester, 490, 513; Gibson, REED Kent, 1.148, 150, 159, 166; REED: Kent, 2.543, 691, 774-5, 851; John R. Elliot (ed.), REED: Oxford (Toronto, 2004), 1.73: Alan B. Somerset (ed.), REED: Shropshire (Toronto, 1994), 75, 77, 182, 185, 189, 196, 198; Lewis, REED: Sussex (Toronto, 2000), 17, 99, 105-7, 109-10; 
Galloway, Norfolk/Suffolk, 148; Thetford Priory, 708; Lancashire, Dramatic Texts, 202, 266, 381-3, 397; Murray, Dramatic Companies, 2.205, 297, 362, 396, 440, 446; Glynne Wickham, Early English Stages, 1300-1660 (London, 1980), 336.

18 David Starkey, Six Wives. The Queens of Henry VIII (New York, 2003), 40.

19 Wasson, REED: Devon, 215.

20 Starkey, Queens, 41.

21 Wasson, REED: Devon, 114.

22 Starkey, Queens, 48-78.

23 Ibid, 75-106.

24 Alan H. Nelson and John R. Elliot, Jr. (eds), REED: Inns of Court (Cambridge, 2010), 1.30. Prince Henry's and Princess Katherine's musicians appeared jointly at Canterbury on 2 July 1507, receiving a joint payment of 3 shillings, 4 pence. Gibson, REED: Kent, 1.103.

25 Starkey, Queens, 93-111.

26 Klausner, REED: Hereford/Worcester, 417; Pilkinton, REED: Bristol, 30; Gibson, REED: Kent, 2.838.

27 Neil Samman, 'The Progresses of Henry VIII', Diarmaid MacCulloch (ed.), The Reign of Henry VIII. Politics, Policy and Piety (London, 1993), 63; Starkey, Queens, $168-72$.

28 A.F. Pollard, Henry VIII (New York, 1966), 50-2, 112-14, 139-43; Starkey, Queens, 142-60, 273-4. Quotation of Henry's remarks on the birth of Princess Mary is from Pollard, Henry VIII, 142.

29 Thetford Priory, 576.

30 Lancashire, Dramatic Texts, 378, Murray, Dramatic Companies, 2.305; Elliot, REED: Oxford, 1.73 .

31 Pollard, Henry VIII, 139; Starkey, Queens, 203-56, 294-304.

32 Starkey, Queens, 149.

33 Ibid, 255, 440-4.

34 Ibid, 459-66, 489-502, 508.

35 Ibid, 462, 490-503

36 Wasson, REED: Devon, 132; Starkey, Queens, 508.

37 Starkey, Queens, 459.

38 Edwin Nungezer, A Dictionary of Actors...in England before 1642 (New York, 1971 rpt. of 1929 ed.), 341; David N. Klausner, REED: Herefordshire/Worcestershire (Toronto, 1990), 530; Lancashire, Dramatic Texts, 389.

39 Nelson, REED: Cambridge, 1.106; Wasson, REED: Devon, 132; Klausner, REED: Hereford/Worcester, 523, 526-7.

40 Starkey, Queens, 545-8. 
41 See Jeffrey Leininger, 'Evangelical "Enterluders": Patronage and Playing in Reformation England', Reformation and Renaissance Review 4 (2002), 48-93. DOI: http:// dx.doi.org/10.1558/rrr.v4i1.48; Paul Whitfield White, Theatre and Reformation (Cambridge, 1993), 43-50.

42 Klausner, REED: Hereford/Worcester, 530; Gibson, REED Kent, 1.147.

43 Starkey, Queens, 550-1, 553-83.

44 Ibid, 591-2.

45 Somerset, REED: Shropshire, 194-5; Lancashire, Dramatic Texts, 395; Starkey, 607-8

46 Starkey, Queens, 617-28.

47 Ibid, 629.

48 Ibid, 630-42. Lancashire (Dramatic Texts, 145) notes 'Masques and other disports for the king and Anne of Cleves one their wedding night'. Henry's entertainers probably performed these 'disports'. In appendix 1 (373) Lancashire suggests 'The queen's players: 1540 Court'. Yet the sources for performances at court do not specify which queen's players. Given Henry's almost immediate attempts to annul the marriage, I think it unlikely that this Queen Anne ever had a formal troupe of entertainers, and that these 'queen's players' belonged to Queen Catherine Howard.

49 Starkey, Queens, 629-31, 637-8, 648-51; Alison Weir, The Six Wives of Henry VIII (New York, 1993), 413; Diarmaid MacCulloch, 'Henry VIII and the Reform of the Church', Reign of Henry VIII, 178-9. For fiction, see, for example, Phillippa Gregory, The Boleyn Inheritance (New York, 2006).

50 Lancashire, Dramatic Texts, 22, 373, 379.

51 Starkey, Queens, 662-84.

52 Ibid, 713.

53 Ibid, 690-701, 697-713.

54 Susan E. James, Catherine Parr. Henry VIII's Last Love (Charleston, 2009), 61-73; Starkey, Queens, 704-7, 729-65.

55 Gibson, REED: Kent, 1.158; Kent, 2.445, 447; Nelson, REED Cambridge, 1.131; Pilkinton, REED: Bristol, 57; Murray, Dramatic Companies, 2.362; Lancashire, Dramatic Texts, 379.

56 Starkey, Queens, 748-51.

57 Ibid, 701-4, 711-13, 728-30, 739-40, 752-9; White Theatre and Reformation, 43-50; Leininger, "Evangelical 'Enterluders," 48-93.

58 David Galloway (ed.), REED: Norwich (Toronto, 1984), 20. White, Theatre and Reformation, 31-7.

59 Lancashire, Dramatic Texts, 272.

60 David M. Loades, Mary Tudor: A Life (Cambridge, 1990), 36-7; Linda Porter, Mary Tudor: The First Queen (London, 2007), 38-9; Starkey, Queens, 200-1. 
61 Nungezer, Dictionary of Actors, 341.

62 Somerset, REED: Shropshire, 75, 182, 185, 189.

63 Lancashire, Dramatic Texts, 266; Murray, Dramatic Companies, 2.297.

64 Pilkinton, REED: Bristol, 42: Klausner, REED: Hereford/Worcester, 487, 489-90, 513; Elliot, REED: Oxford, 1.72; Gibson, REED: Kent, 2.429-30.

65 Lancaster, Dramatic Texts, 397.

66 Pollard, Henry VIII, 142.

67 Beverley A. Murphy, Bastard Prince: Henry VIII's Lost Son (Stroud, 2001), 42.

68 Murphy, Bastard Prince, 61; Starkey, Queens, 202-3.

69 Ibid, 172-4, 243.

70 Wasson, REED: Devon, 128; REED Somerset, 43; James Stokes (ed.), REED: Lincolnshire (Toronto, 2009), 1. 343-4.

71 Pilkinton, REED: Bristol, 42, 45; Gibson, REED: Kent, 2.843, 849; Nelson, REED: Cambridge, 1.106; Wasson, REED: Devon, 128; Lewis, REED: Sussex, 99, 103; Somerset, REED: Shropshire, 189; Galloway and Wasson, Norfolk and Suffolk, 148, Wickham Stages, 336.

72 Starkey, Queens, 600.

73 Pilkinton, REED: Bristol, 46.

74 Starkey, Queens, 607.

75 Nelson, REED: Cambridge, 1.115; Wasson, REED: Devon, 135, 227.

76 Ibid, REED: Cambridge, 1.116, 118; Wasson, REED: Devon, 138, 228; Rosalind Conklin Hays, C.E. McGee, Sally Joyce, and Evelyn S. Newlyn (eds), REED: Dorset, Cornwall (Toronto, 1999), 473; Somerset, REED: Shropshire, 196; Lewis, REED: Sussex, 106; Murray, Dramatic Companies, 2.298, 396; Thetford Priory, 708.

77 Nelson, REED: Cambridge, 1.119; Pilkinton, REED: Bristol, 50-51; Wasson, REED: Devon, 228; Gibson, REED: Kent, 1.150, 154; REED: Kent, 2.440, 442, 543, 691-2, 774, 851; Galloway, REED: Norwich, 8; Somerset, REED: Shropshire, 77-8; Lewis, REED: Sussex, 106-7; Lancashire, Dramatic Texts, 381-3; Murray, Dramatic Companies, 2.285.

78 Christopher Skidmore, Edward VI: The Lost King of England (London, 2007), 2835; Starkey, Queens, 735-7.

79 Pilkinton, REED: Bristol, 54; Nelson, REED: Cambridge, 1.130; Wasson, REED: Devon, 40, 231; Gibson, REED: Kent, 1.159; REED: Kent, 2.443-4, 775; Galloway, REED: Norwich, 13; Somerset, REED: Shropshire, 77; Lewis, REED: Sussex, 17, 18, 109-10; Lancashire, Dramatic Texts, 381-3; Murray, Dramatic Companies, 2.362.

80 Gibson, REED: Kent, 1.166, 2.579, 775; Galloway, REED: Norwich, 14, 20; Lewis, REED: Sussex, 110. 
90 James H. Forse

81 Nungezer, Dictionary of Actors, 331-2, 403; Klausner, REED: Hereford/Worcester, 513; Wasson, REED: Devon, 42; James Stokes and Robert J. Alexander (eds), REED: Somerset Including Bath (Toronto, 1996), 1.57.

82 Starkey, Queens, 627-32.

83 Tennenhouse, Power on Display, 3

84 Forse, 'Getting Your Name Out There', 133-5.

85 Data in the table from: Nelson, REED: Cambridge, 1.63, 69, 74, 77; Wasson, REED: Devon, 32, 35; Klausner, REED: Hereford/Worcester, 401-5; Gibson, REED: Kent, 1.20, 78-82, 84, 89, 91-4, 97; REED: Kent, 2.355, 357, 360-1, 367, 370-1, 373, 376, 379, 383-5, 475, 2.618-21, 623-5, 668-71, 740-1, 743-4, 750-2, 754, 756, 829; Somerset, REED: Shropshire, 149-50, 152, 161-2; Stokes, REED: Somerset, 1.251-2; Lewis, REED: Sussex, 50-2, 54, 59, 62, 69, 184.

86 Data in the table from: Nelson, REED: Cambridge. 1.7, 63; Wasson, REED: Devon, 34-5, 215-16; Hays, Dorset, Cornwall, 493; Klausner, REED: Hereford/Worcester, 405; Gibson, REED: Kent, 1.81-2, 89, 94, 97, 99, 102-3, 107; REED: Kent, 2.353, 358, 360, 375, 377, 381, 384, 389-95, 570, 2.616, 619, 624-8, 740, 742, 751, 7534, 756, 759-60, 831, 833; Stokes, REED: Lincolnshire, 1.79, Elliot, REED: Oxford, 1.25, Somerset, REED: Shropshire, 148, 152-3, 162, Stokes, REED: Somerset, 1.252-3, Lewis, REED: Sussex, 53, 61-2, 64, 689, 71-4, 77, 86; Alexandra F. Johnson and Margaret Rogerson (eds.), REED: York, 102; Lancashire, Dramatic Texts, 374, 38992; Thetford Priory, 102, 137, 180, 190, 223; Wickham, Stages, 334. 